DOI: $10.15587 / 2312-8372.2017 .90448$

\section{Pataraia L., Geradze R., Dushuashvili T.}

\title{
FINANCIAL SECTOR ANALYSIS IN THE CLUSTER THEORY CONTEXT (GEORGIAN CASE)
}

Дано оцінку фінансовим послугам в Грузї в контексті кластерної теорії. Визначено шляхи представлення кластеру, динаміку його мінливості, темпи зростання, реалізацію його потенціалу i перешкод, з якими він стикається. Встановлено, що існує неповна форма фінансових послуг торгового кластеру в Тбілісі, яка знаходиться ще на стадї свого розвитку.

ключові слова: кластерна карта, «конкурентний ромб» Портера, фінансовий сектор Грузіі, кредитні установи, фондові біржі.

\section{Introduction}

Financial sector development is a vital component for the economy of Georgia. It is one of the most important factors contributing to the creation of new jobs as well as for the ensuring of the sustainable economic development and innovations.

Moreover, the financial sector has a positive spillover effect on other sectors - many cultural, social, health care and charitable projects benefit from the contribution of the sector. Through the initiatives and the financial support of the country's largest commercial banks, several social projects in the different fields had been launched.

Through the development of the financial system in Georgia the topic of financial service clustering emerged. Financial institutions started growing and the demand on the highly specialized workers increased. Financial institutions started Annexation of the related sub sectors in the field.

Why Financial Cluster?

- The institutions of the financial sector are one of the largest employers in Georgia.

- According to the existing literature, a financial cluster increases productivity and efficiency of the specialization, information, institutions and qualified human resources through the better access [1].

- The financial sector has the highest real growth rate (in the last 10 years an average real growth rate of the financial activities reached 16,6\%) [2].

- Financial sector employees have the highest average salary (according to the data of 2015, financial sector employees' average monthly salary is 1,590 GEL (700 USD) while the average monthly salary of hired employees is 818 GEL (360 USD)), which is reflected in tax receipts. The high rate of the average salary indicates the intensified interest in employment and the high demand for the specialized education [2]

\section{The object of research and its technological audit}

For the purposes of this work, a financial cluster is defined as a unity of sub-clusters, such as commercial banks, microfinance institutions, credit unions, insurance companies, pension funds and the stock market. The ef- ficiency of financial services is estimated on the bases of concentration per location, employment, education accessibility, and the volume of capital investments, GDP growth rate, the average profitability and the rate of innovation.

\section{The aim and objectives of research}

The aim of the research is to identify the ways of the cluster, the dynamics of its variability, the growth rates as well as the realization of its potential and obstacles for it.

To achieve this aim the following objective was set:

1. Identify the unity of the interrelated institutions involved in the financial services as being a necessary condition for the formation of the clusters in the sector.

2. Assess the location-based business environment, which plays a crucial role in the global and local competitiveness. Its effectiveness is determined through the following characteristics:

- Factor Conditions (the cost and quality of inputs).

- Demand Conditions (local customers demand levels).

- Company's concept, strategy/competition (nature and intensity of the local competition).

- Related and supporting industries (quality and smartness of the local suppliers and related industries).

The Diamond Model reflects a combination of those factors, which provide a dynamic, stimulating and intensive business environment. Placing companies, customers and suppliers closely together accelerates innovations and lays the foundation for renewal.

\section{Research of existing solutions of the problem}

Historical and intellectual preconditions of cluster theory in terms of trade and geographic concentration counts for centuries. Alfred Marshall was one of the first scientists who have focused on the industry location [3]. It is also important that neoclassical economics was ignoring the importance of geographical locations, until recent theories of globalization, international trade and growth in which economic geography and clusters are holding the leading positions [4-8].

Cluster theory substantially changes importance of location in the global competition [9]. Clusters have 
integrated role in modern economy. In the framework of competition, the integrated nature of cluster gives us a generalized picture, combining the leading principles of modern management, such as costs, differentiation, efficiency, innovation and global markets [10, 11].

Most of the literature argues that as cluster is naturally aroused complex system, it is difficult to copy. For the first reason researchers nominate existence of research, innovation, skilled workforce and infrastructure for a particular region, which is precondition for future innovations. For the second reason structural links between firms and institutions are established within a specific region, coping of which for the other regions is difficult [12].

Several important types of clusters were distinguished by Markunsen [13], which differentiates clusters according to following indicators:

Firm size, which reflects the potential for the realization of economies of scale.

Relationship level between companies, suppliers and customers within the cluster.

Internal or external orientation level of the cluster.

Economic agglomeration level. Marshall's new industrial region (NID) of small local firms also represents one more type of classical cluster [3].

As regards to financial services cluster, only scares literature exists on this direction [14-16]. The latest statistical studies show that firms which are located in the financial services cluster are rapidly growing and their benefits are similar of high-tech industries [17-19].

\section{Methods of research}

A financial service cluster is defined with a narrow focus of The Cluster Observatory, which is based on the statistical classification of economic activities in the European Community established by the Eurostat (NACE 2.0). We defined the following constituent industries of the Georgian financial service cluster: banks, stock exchanges, insurance companies, pension funds, microfinance institutions, credit unions, money transfer entities and currency exchange bureaus [20]. The strongest players are credit (commercial banks and microfinance institutions) and insurance (private insurance companies) institutions (Fig. 1).

After defining the cluster, we measured its effectiveness using the Diamond Model and its productivity by analyzing macroeconomic parameters, such as employment, education accessibility, the volume of capital investments, GDP growth rate, average profitability, the rate of innovation and concentration per location.

5.1. Review of Financial Cluster Sub-sectors. 5.1.1. Commercial Banks. According to the data of December 2015, there are 19 commercial banks in Georgia [2]. In total, the bank's equity capital exceeds 3,5 B GEL (1,5 B USD). In 2015, Georgian banking sector's net profit was 537,4 M, which is $13,2 \%$ more than the one for the same period of 2014. In 2015, commercial banks' return on equity amounted to $15 \%$, while the return on assets equaled to $2 \%$. These figures were characterized with certain fluctuations, especially true for the intervals between 2008-2009 and 2011-2012. In recent years, the banking sector's profitability index has been stable. The sector has a tendency of growth regarding both, the national and foreign currency savings as well as the volume of foreign direct investments. By December 2015, non-bank deposits amounted to 14,3 B GEL (6,3 billion USD), which is the increase by $2,3 \%$ compared to the previous year (neglecting the exchange rate effect).

Regulatory Authorities:

- National Bank of Georgia

- Insurance State Supervision Service of Georgia

- Ministry of Finance of Georgia

- Financial Monitoring Service of Georgia

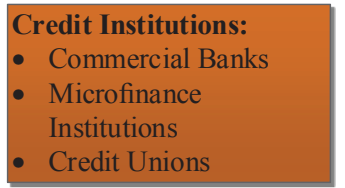

The securities market: - Stock Exchange

\begin{tabular}{|l|}
\hline Funds: \\
- State Governed Pension \\
Fund \\
- Private Pension Funds \\
\hline
\end{tabular}

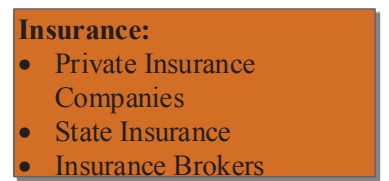

\begin{tabular}{|l|}
\hline Related Individual \\
Players: \\
- Money Transfer \\
Entities \\
- Currency Exchange \\
Bureaus \\
\hline \\
\hline
\end{tabular}

Related Industries:

- International Investors (The World Bank, International Monetary Fund and etc.)

- Financial Consulting;

- Real Estate Markets;

- Specialized education;

- Communications and IT;

- Leasing Companies;

- Audit Firms;

Strong Players

Weak Players

Fig. 1. Financial Services Cluster Map 
A depreciation of the national currency in 2015 led to a notable decrease in the volume of the deposits. According to the data of December 2015, the total amount of the national currency deposits of the natural and legal persons attracted by the commercial banks amounted to 4,6 B GEL (2 B USD), which is $6,4 \%$ lower than the figures of the previous year. In the meantime, the foreign currency deposits of the legal entities and the individuals reached 10,9 B GEL (4,8 B USD), which is 45,4 \% higher compared to 2014.

The sector has an increasing employment rate. According to the data of the National Statistics Office of Georgia, the number of employees in commercial banks has been growing annually by $7 \%$ during the last 5 years.

According to the data of September 30, 2015, approximately $74 \%$ of the market share (by total assets) falls on the four commercial banks. Respectively, concentration index for banking sector is also high for Georgia. HHI (Herfindahl-Hirschman Index) index for September 2015 was 2 050. Bank product diversity on the Georgian market is customized to the current economic situation in the country (e. g. GEL exchange rate fluctuation led to the emergence of such products as convertible deposit). The banks also care about their own development (new products are continuously introduced on the market) and technological progress (internet banking, on-line banking, mobile banking, phone banking, SMS banking). Internet banking service is provided by almost every commercial bank operating in Georgia, SMS and Telephone Banking can be found in the majority of the banks $(71 \%)$, while the Mobile Banking is offered by only $41 \%$.

5.1.2. Insurance Market. According to the data of 2015, there are 14 insurance companies and 20 insurance brokers in Georgia. By September 30, 2015, the country had 1357194 active insurance policies. The largest share of issued policies, $39 \%$ - falls onto the health insurance, $24 \%$ - life insurance, $12 \%$ - accident insurance and $8 \%$ - travel insurance [21].

In the last 5 years, the insurance premiums attracted by the insurance companies tend to be fluctuated. In 2013-2014, due to the decrease in the health insurance premiums a sharp drop in the attracted premiums was observed. The decline is due to the state health insurance program, the first stage of which started in February of 2013 and was followed by the second stage in July, 2013. Although some customers switched to the state insurance, the private insurance still retains its relevance and functions, as since 2015 health insurance premiums have been increased comparing to the previous year. Therefore, the sector might be characterized as stable. The number of employees in the sector has also increased. According to the National Statistics Office of Georgia, in the third quarter of 2015, the number of employees of the insurance sector was increased by $9 \%$ compared to the same period of 2014 .

5.1.3. Non-bank Depository Institutions. By 2015, there are 15 non-bank depositary institutions in Georgia. Since 2008, the volume of credit union assets has a growing trend. By the $4^{\text {th }}$ quarter of 2015 , the total assets of non-bank depositary institutions reached 9,5 M GEL (4,2 M USD), which is $17 \%$ higher comparing to the previous year. By the same period, the total volume of deposits of credit unions reached 6.3 million, which is $18 \%$ higher than the figures of the same period of 2014 .
5.1.4. Microfinance Institutions. There are 69 MFO-s registered in Georgia by December 2015 [22]. The number of employees in the microfinance institutions has been also increased annually. According to the data of the fourth quarter of 2015, micro-finance organizations employed in total 4901 people, which is $20 \%$ higher than the figures of 2014 . In the last 5 years, the number of employees in the microfinance organizations annually has been grown by $21 \%$ on average. In the fourth quarter of 2015 , the total assets of microfinance institutions increased by 1,6 B GEL (0,7 B USD), which is $46 \%$ higher than the figures of 2014 .

5.1.5. Stock Exchange. Georgian Stock Exchange trading system allows the securities for 128 companies (March 1, 2016). Cumulative information on transactions (shares) is characterized by the significant fluctuations during the years. The trend of growth in the number of transactions was observed until 2007, however, since 2008 the number of fixed transactions decreased and equaled to total 246 transactions [23].

5.2. Comparative Analysis of Peer Countries. For comparative analysis we took countries, whose history, geographical location or demographic indicators were similar of Georgia. All of the selected peer countries were members of former Soviet Union. Geographical location of Georgia, is near to Armenia and Azerbaijan, while the demographic data of the country is similar to the Baltic States: Lithuania, Latvia and Estonia. Consequently, these countries were been selected for comparative analysis.

5.2.1. Commercial Banks. Georgian banking sector is somewhat similar to the banking industries in the Baltic States, Armenia and Azerbaijan. In Georgia, Armenia and Azerbaijan, banking sectors account respectively for $95 \%$, $89 \%$ and $93 \%$ of the entire financial sectors assets and in all cases microfinance and insurance sectors are at an early stage of development.

However, there are some differentiating aspects, because of abundance of natural resources, unlike Georgia, Azerbaijan does not rely heavily on financial service industries. Banks in Azerbaijan also do not have much of a cross-border activities or abundance of subsidiaries in foreign countries, they mainly focus on the domestic needs of their customers [24].

Unlike Georgia's case, starting from 2006, Baltic Banks have performed many mergers and acquisitions and opened subsidiaries across the borders of Lithuania, Latvia and Estonia [25-28]. However, Georgian banking system is more concentrated than the Baltic one. The HHI Index among these countries is the highest in Georgia.

5.2.2. Insurance Market. In Georgia, small financial service providers are highly dependent on large banks and some are even owned by them. Insurance sector might be classified as developing, as its portion to the country's GDP remains low in single digits. There is big room for growth for insurance market in Georgia, which is slowly being filled with several big insurance companies, raising entry barriers for new entrants.

Insurance market in Azerbaijan and Armenia is just as small as it is in Georgia, however, it is less concentrated. Baltic Insurance market is bigger in size and more dependent on the individual countries.

5.2.3. Microfinance Institutions. There are large and reliable banks in Georgia, making the market concentrated. This makes it challenging for new microfinance to enter the market and not be run out of business. These large 
banks also try to expand their reach and acquire brokerages, insurance companies and microfinance organization further increasing their market share and the costs associated with entering the business.

Even though MFOs are actively trying to develop, microfinance sector in Georgia still remains small and concentrated. Microfinance sector accounts for less than $1 \%$ of the GDP, in Azerbaijan this estimate is about $1 \%$ as well. However, the market in Azerbaijan is slightly less concentrated, with top two MFOs having approximately $50 \%$ of the market. Both Azerbaijani and Georgian microfinance sectors are focused on domestic customer base [24].

5.2.4. Stock Exchange. There is a small market for securities in Georgia, Georgia Stock Exchange (GSE). GSE facilitates both local and foreign investor demands to buy and sell financial obligations.

On a domestic level, securities exchange market is still small, highly concentrated and underdeveloped, which might be due to low demand for such services. Moreover, securities market has big potential for growth in Georgia.

Azerbaijan's securities market and the Baku Stock Exchange in particular are relatively smaller and more secluded from the international markets than the Georgian one. Armenian Stock Exchange, NASDAQ OMX Armenia is an open joint stock company. Similar to Georgia's case, Central Bank of Armenia operates the NASDAQ OMX Armenia, which trades stocks, government, corporate and CBA bonds, as well as currency. NASDAQ Armenia is also part of Federation of Euro-Asian Stock Exchange and International Association of CIS Exchange, which makes the reputation of the company highly reliable and investor-friendly.

Armenian and Georgian stock exchange companies have more similar operating activities that are somewhat different from the Baltic tradition. Baltic exchange, the NASDAQ Baltic serves customers in all three of the Baltic countries, satisfies the needs of three individual countries' financial sector users and has strong relations with the Nordic exchange companies. Because the Baltic States are so economically and financially interdependent, there is a need for a unified, open securities exchange market. This way, the Baltic States have easier access to capital, labor and knowledge and also diminish the costs associated with cross-border trading. Majority of the Baltic financial service provider firms also have high proportion of foreign investors, which creates high demand for a reliable, international and unified securities exchange company [29]. The same is true for Georgian financial sector, where majority of the investors are international and require impartial securities exchange company.

\section{Research results}

Georgia's financial cluster can be determined as a growing cluster. As we see from the Diamond Model, the main part of its strengths is in the parts of the factor conditions and the strategies/competitiveness of the clusterconstituent firms.

6.1. Company Concept, Strategy/Competition. Georgian financial sector is fully open to foreign investments. It is obvious because in 2015, the investment volume in the sector reached $180 \mathrm{M}$ USD, which is $11 \%$ of the total investments in the country. There are no barriers to capital inflow. There are large market players in Georgia. Approximately $74 \%$ of the market share (by total assets) accounts to the 4 commercial banks, while $57 \%$ of the attracted insurance premiums are distributed among the 3 insurance companies. However, there is an open competition between the large companies on the market. Their production is diversified and innovative. The strategies and the competition within the cluster institutions are negatively impacted by the weakness of the Antitrust Law, lack of regulations for certain institutions (loan issuing online companies), the national currency volatility, and the unstable current political and economic environment in the country.

6.2. Factor Conditions. The financial education is obviously characterized by the high demand as well as the supply in Georgia. Almost every accredited university curricula has a program in finances. Such courses are also available in vocational institutions and the state funded program allows anyone to obtain knowledge of the financial sphere. The number of students enrolled for the financial programs is very high. According to the data of 2015 , graduates with degree in finance are approximately one quarter of the total number of graduates. However, despite the availability of education and the request for extension of the studies, the quality of the financial education is still low. One of the shortages of the factor conditions is that few resources are available for research and development practice. There is also little access to the finances for rural populations and the firms have a high dependence on the international capital. In Georgia, 18 commercial banks out of 19 are managed with the means of foreign capital, while the one is a branch of a non-resident bank.

6.3. Demand Conditions. The financial demand of the population as well as the businesses is very high. The absolute majority of the population uses credits. However, since the dollarization rate remains high, the level of savings is very low. The financial education of the people is also rather poor. According to the research of the ISET/TNS, financial education is poor among $52 \%$ of surveyed informants, $42 \%$ of them were marked with an average level, while only $6 \%$ revealed the signs of high indicator.

6.4. Related and Supporting Industries. In Georgia, there is a large number of financial service supporting institutions (Telecommunications, IT, accounting firms, audit companies, real estate development companies, financial media). As for the related institutions, the Real Estate Market is marked with a fast development trend, while the Stock Market of Georgia is less developed. According to the data of 2015, there are 5 pension funds in Georgia, whose activities are also relatively low (Fig. 2).

As for the productivity of the cluster, it was estimated on the basis of macro-economic parameters. For the last 10 years financial sector had the highest real growth rate. Average real growth rate of the financial activities reached $16,6 \%$. In 2015, the GDP in the financial activities amounted $1044,5 \mathrm{M}$ Gel (460,1 M USD), while financial activities accounted for $3,8 \%$ of GDP [30].

As regards to concentration, the data clearly shows that the absolute majority of financial services sub-sectors are located in Tbilisi (absolute majority of largest players of financial services cluster (commercial banks and insurance companies) can be found in Tbilisi. $45 \%$ of all commercial banks and its branches and $29 \%$ of all insurance companies and its branches are concentrated in the capital) and there can be found only small part of financial institutions in the regions. Consequently, the financial services cluster in terms of location is confirmed only in Tbilisi. 


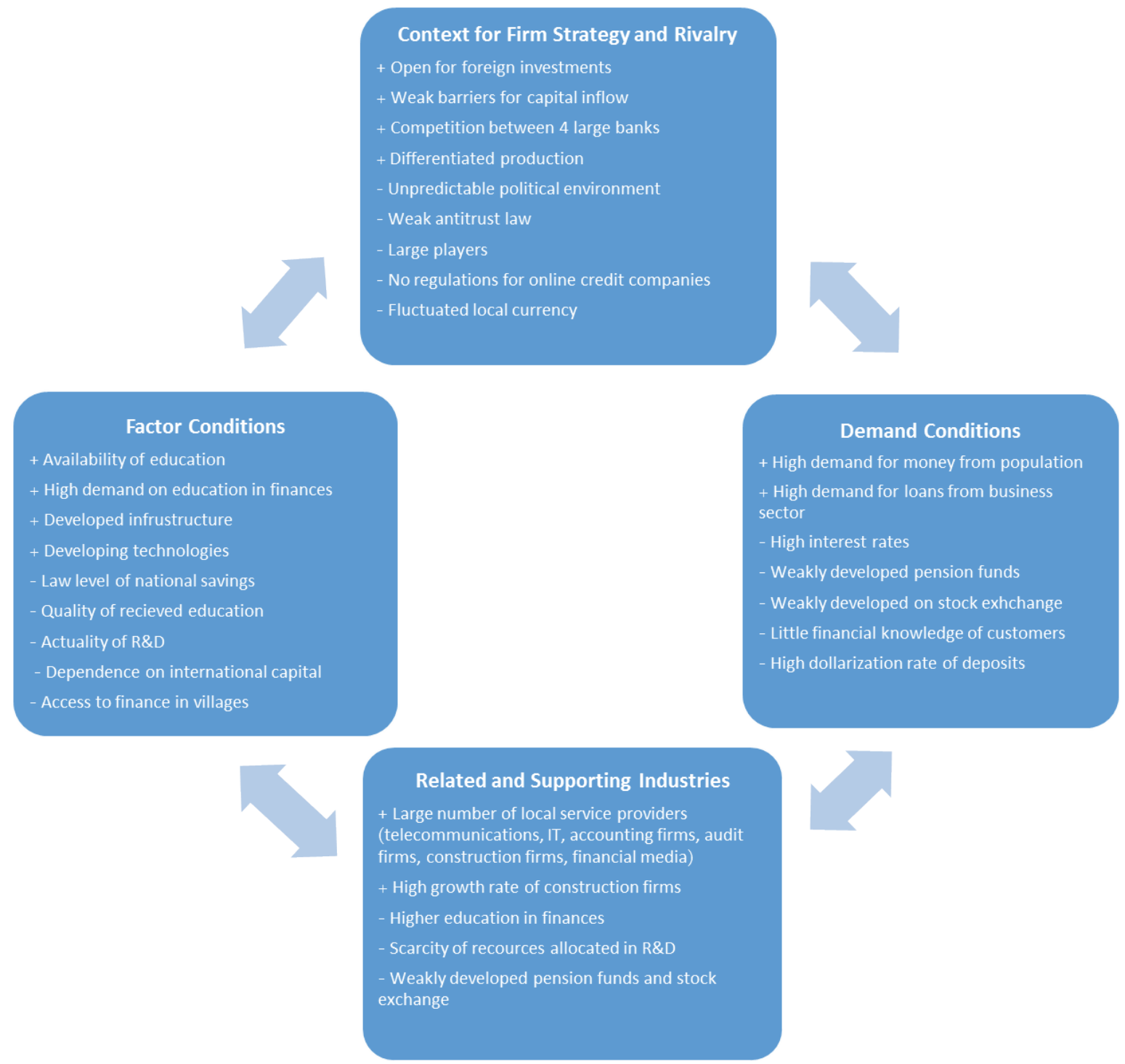

Fig. 2. Financial Services Cluster Diamond Model

\section{SWOT analysis of research results}

As it can be seen from above discussion, cluster industries are more focused on innovations and adapt more quickly than non-cluster industries. Therefore, the financial cluster allows the rapid transformation of the sector and helps it to reach the level of global competitiveness, which should be one of the priorities of the State and its strategic vision in this area and the policy development should be based on the existing perspectives.

The strengths of this research is that it reviews all the key sub-sectors of Georgian financial cluster and gives a reader detailed analysis of their development trends. Places all the players on the financial services cluster map and identifies strong and weak players of the sector. It also places all the sub sectors to the framework of the Diamond Model, which on the other hand reflects a combination of the factors, which provide a dynamic, stimulating and intensive business environment.

Weakness of this research is that it does not control for the potential negative effects of the financial cluster. Clustering is always related to the monopolization risk, because there is a high concentration of the businesses.
Therefore cluster can gain dominant power on the market and this is especially true for the small economies.

There is a huge room for the further research especially to the direction of cost benefit analysis of the financial cluster. The most important is to analyze spillover effects of financial service cluster on the other sectors and economy as a whole.

\section{Conclusions}

As a result of the research, we can assume that the financial cluster of Georgia exists and is at the stage of its development. Georgian financial sector is recognized as a regional hub with its high growth rates and progressive realization of its potential. This is confirmed by the quantitative measurement of the variables which are highly concentrating on specific locations (institutions, their branches, products offered and the average wages in the sector, etc.), but for a cluster to continue the organic growth and development, it is crucial to improve the qualitative indicators in addition to the quantitative parameters. It is directly related to the development of innovations in the sector, active involvement of the edu- 
cational sphere and offering a variety of programs, which will deliver the focused specialties for the sector and increase the labor competitiveness in the global context.

Cluster industries are more focused on innovations and adapt more quickly than non-cluster industries. Therefore, the financial cluster allows the rapid transformation of the sector and helps it to reach the level of global competitiveness, which should be one of the priorities of the State and its strategic vision in this area and the policy development should be based on the existing perspectives.

From all above mentioned we recommend the following:

- Develop antitrust law for protecting investors and depositors. There is given a platform to attract more financial resources because interest rates in commercial banks and micro financial organizations are significantly high and fluctuate from $5 \%$ to $18 \%$. Though, legislative framework is weak and needs to be improved.

- Online financial credit organizations are not regulated and the life cycle of such institutions is approximately 3 years, they end up with bankruptcy. This risk can be eliminated by involving Central Bank to develop regulatory policy.

- Develop precised narrow specialization in finance and improve vocational education. Decreasing existing information asymmetry between the financial sector considering work force demands and education system.

- Initiate regional stock exchange markets and improve financial services between trading partner countries. Georgia has unique historical conditions and good experience in regional stock markets and can share the values between co-partners.

- Establish pension funds and attract beneficiaries and private financial institutions by raising awareness. - Improve infrastructure for economically non-active locations and stimulate demand for financial services. - Develop research centers for gathering big data of financial service which will play significant role in creating innovative services/products.

\section{References}

1. Porter, M. E. Clusters and New Economics of Competition [Text] / M. E. Porter. - Harvard Business School Press, 1998. - 16 p.

2. National Statistics Office of Georgia [Electronic resource]. - Available at: \www/URL: http://www.geostat.ge/index.php?lang=eng

3. Marshall, A. Principles of Economics [Text] / A. Marshall. London: Palgrave Macmillan UK, 2013. - 182 p. doi:10.1057/ 9781137375261

4. Clark, G. L. The Oxford Handbook of Economic Geography [Text] / G. L. Clark, M. P. Feldman, M. S. Gertler, K. Williams. - Oxford University Press, 2009. - 776 p.

5. Karlson, C. Handbook of Research on Cluster Theory [Text] / C. Karlson. - Edward Elgar, 2008. - 336 p. doi:10.4337/ 9781848442849

6. Krugman, P. Increasing Returns and Economic Geography [Text] / P. Krugman // Journal of Political Economy. - 1991. - Vol. 99, № 3. - P. 483-499. doi:10.1086/261763

7. Porter, M. E. On Competition [Text] / M. E. Porter. - Harvard Business School Pr, 2008. - 485 p.

8. Porter, M. E. The Global Competitiveness Report $2007-$ 2008 [Text] / M. E. Porter, K. Schwab, X. Sala-I-Martin. Palgrave Macmillan, 2007. - 608 p.

9. Andersen, P. Cluster-based global firms' use of local capabilities [Text] / P. Andersen, A. Bollingtoft // Management
Research Review. - 2011. - Vol. 34, № 10. - P. 1087-1106. doi:10.1108/01409171111171492

10. Breault, R. The Evolution of Clusters and Structured Economic Development regions and Their Future [Text] / R. Breault. - Tucson, Arizona: Breault Research Organization, Inc., 1997. - 540 p.

11. Iwuagwu, O. Nigeria and the challenge of industrial development: The new clusters strategy [Text] / O. Iwuagwu // African Economic History. - 2009. - Vol. 37. - P. 151-180.

12. Maskell, P. Localised learning and industrial competitiveness [Text] / P. Maskell // Cambridge Journal of Economics. 1999. - Vol. 23, № 2. - P. 167-185. doi:10.1093/cje/23.2.167

13. Markusen, A. Sticky Places in Slippery Space: A Typology of Industrial Districts [Text] / A. Markusen // Economic Geography. - 1996. - Vol. 72, № 3. - P. 293-313. doi:10.2307/144402

14. Odedokun, M. O. Alternative econometric approaches for analysing the role of the financial sector in economic growth: Time-series evidence from LDCs [Text] / M. O. Odedokun // Journal of Development Economics. - 1996. - Vol. 50, № 1. P. 119-146. doi:10.1016/0304-3878(96)00006-5

15. Pandit, N. R. Knowledge and Innovation: Insights from the British Financial Services Industry [Text] / N. R. Pandit, G. Cook // Journal of Financial Services Marketing. - 2003. P. $230-245$.

16. Taylor, P. Financial Services Clustering and its significance for London. Full Report [Text] / P. Taylor et al. - London: Corporation of London, 2003. - $116 \mathrm{p}$

17. Allen, K. UK Competitiveness and the International Financial Services Cluster in London [Text] / K. Allen et al. - Harvard Business School, 2007. - 32 p.

18. Pandit, N. R. The Dynamics of Industrial Clustering in British Financial Services [Text] / N. R. Pandit, G. A. S. Cook, P. G. M. Swann // The Service Industries Journal. - 2001. Vol. 21, № 4. - P. 33-61. doi:10.1080/714005045

19. Swann, P. A comparison of the dynamics of industrial clustering in computing and biotechnology [Text] / P. Swann, M. Prevezer // Research Policy. - 1996. - Vol. 25, № 7. P. 1139-1157. doi:10.1016/s0048-7333(96)00897-9

20. Delgado, M. Defining clusters of related industries [Text] M. Delgado, M. E. Porter, S. Stern // Journal of Economic Geography. - 2015. - Vol. 16, № 1. - P. 1-38. doi:10.1093/ jeg/lbv017

21. Statistics [Electronic resource] // LEPL Insurance State Supervision Service of Georgia. - Available at: \www/URL: http://www.insurance.gov.ge/Statistics.aspx

22. Statistical Data [Electronic resource] // National Bank Of Georgia. - Available at: \www/URL: https://www.nbg.gov.ge/ index.php? $\mathrm{m}=304 \& \operatorname{lng}=\mathrm{eng}$

23. Georgian Stock Exchange [Electronic resource]. - Available at: \www/URL: http://www.gse.ge/

24. Conrad, J. F. Azerbaijan: Financial Sector Assessment [Elec tronic resource] / J. F. Conrad. - ADB Central and West Asia Working Paper Series. - Asia Development Bank, 2012. № 3. - 33 p. - Available at: \www/URL: http://www.adb. org/sites/default/files/publication/30098/azerbaijan-financialsector-assessment.pdf

25. Balkevicius, A. Financial sector and its human resources evolution in Baltic States [Electronic resource] / A. Balkevicius // RELIK 2013. Reprodukce lidského kapitálu - vzájemné vazby a souvislosti. 9.-10. prosince 2013. - Available at: \www/ URL: http://kdem.vse.cz/resources/relik13/sbornik/download/ pdf/80-Balkevicius-Arturas-paper.pdf

26. Balkevicius, A. Baltic States Banking Sector Evolution [Text] A. Balkevicius // Annals of the Alexandru Ioan Cuza University - Economics. - 2014. - Vol. 61, № 2. - P. 119-131. doi:10.2478/aicue-2014-0015

27. Benkovskis, K. Is there a Bank Lending Channel of Monetary Policy in Latvia? Evidence from Bank Level Data [Text] / K. Benkovskis. - Latvijas Banka, 2008. - Available at: \www/ URL: https://www.bank.lv/public_files/images/img_lb/izdevumi/english/citas/wp_2008-1 benkovsky.pdf 
28. Jakobsons, A. Study on the Present Competitive Performance and Future Prospects of the Banking Industry in Latvia [Text] A. Jakobsons, W. C. Schaub. - Riga Business School, 2014. Available at: \www/URL: http://www.rbs.lv/files/rbs/Study\%20 on $\% 20$ the $\% 20$ Present $\% 20$ Competitive\%20Performance $\% 20$ and $\% 20$ Future $\% 20$ Prospects $\% 20$ of $\% 20$ the $\% 20$ Banking $\% 20$ Industry\%20in\%20Latvia .pdf

29. Staehr, K. Economic Growth and Convergence in the Baltic States: Caught in a Middle-Income Trap? [Text] / K. Staehr // Intereconomics. - 2015. - Vol. 50, № 5. - P. 274-280. doi:10.1007/s10272-015-0551-1

30. Porter, M. E. Competitive Advantage: Creating and Sustaining Superior Performance [Text] / M. E. Porter. - Free Press, 1998. - 592 p.

\section{АНАЛИЗ ФИНАНСОВОГО СЕКТОРА В РАЗРЕЗЕ КЛАСТЕРНОЙ ТЕОРИИ НА ПРИМЕРЕ ГРУЗИИ}

Дана оценка финансовых услуг в Грузии в контексте кластерной теории. Определены пути представления кластера, дина- мика его изменчивости, темпы роста, реализация его потенциала и препятствий, с которыми он сталкивается. Установлено, что существует неполная форма финансовых услуг торгового кластера в Тбилиси, которая находится еще на стадии своего развития

ключевые слова: кластерная карта, «конкурентный ромб» Портера, финансовый сектор Грузии, кредитные учреждения, фондовые биржи.

Pataraia Larisa, Researcher, Business School, Ilia State University, Tbilisi, Georgia, e-mail: Larisa pataraia@iliauni.edu.ge, ORCID: http://orcid.org/0000-0003-4621-535X

Geradze Revaz, Researcher, Business School, Ilia State University Tbilisi, Georgia, e-mail: revaz.geradze@iliauni.edu.ge, ORCID: http://orcid.org/0000-0001-5161-0595

Dushuashvili Tatuli, Researcher, Business School, Ilia State University, Thilisi, Georgia, e-mail: tatuli.dushuashvili@gmail.com, ORCID: http://orcid.org/0000-0002-5090-613X

Березіна С. $\mathbf{5}$. ВИЗНАЧЕННЯ ЕВРОПЕЙСЬКОГО ВЕКТОРУ
РОЗВИТКУ СТРАХУВАННЯ ЦИВІЛЬНОї
ВІДПОВІДАЛЬНОСТІ ВЛАСНИКІВ
АВТОТРАНСПОРТНИХ ЗАСОБІВ

Проведено аналіз послуг з обов'язкового страхування циивільної відповідальності власників автотранспортних засобів. Розглянуто динаміку обсягу страхових послуг з обов'язкового страхування иивільної відповідальності власників наземних транспортних засобів міжнародного та внутрішнього сегменту страхового ринку України. Виявлені ключові орієнтири наближення обов'язкового страхування иивільної відповідальності власників автотранспортних засобів до європейсъких стандартів.

Ключові слова: страхування цивільної відповідальності власників наземних транспортних засобів, поліс «Зелена картка».

\section{Beтуп}

У зв'язку з прискореним зростанням кількості автомобільного транспорту у світових масштабах, відповідним ущільненням транспортних потоків, завантаженням світової дорожньо-транспортної мережі та, як наслідок, збільшенням кількості дорожньо-транспортних пригод, виникає необхідність дослідження ринку автотранспортного страхування. В тому числі ринку обов'язкового страхування цивільної відповідальності власників наземних транспортних засобів.

Автотранспортне страхування дозволяє комплексно застрахувати самі транспортні засоби, багаж та додаткове автомобільне обладнання, а також водіїв та пасажирів у разі заподіяння шкоди їм самим чи третім особам. Страхування автомобільного транспорту є одним 3 основних секторів в структурі non-life страхування в багатьох країнах світу. Зокрема, його частка на страховому ринку Європейського Союзу становить майже 30 \% від загального обсягу ризикових премій.

Різновидом автотранспортного страхування є обов'язкове страхування цивільно-правової відповідальності влас- ників наземних транспортних засобів (ОСЦПВВНТЗ). Дане страхування здійснюється з метою забезпечення компенсації шкоди, заподіяної життю, здоров'ю та/або майну постраждалих внаслідок дорожньо-транспортної пригоди та захисту майнових інтересів страхувальників. Рівень розвитку ОСЦПВВНТЗ на страховому ринку України відстає від рівня зарубіжних ринків. В умовах європейської інтеграції існує гостра необхідність пошуку шляхів наближення обов'язкового страхування цивільної відповідальності власників автотранспортних засобів до європейських стандартів.

\section{2. Об'ект дослідження та його технологічний аудит}

Об'єкт дослідження - український ринок ОСЦПВВНТЗ, основна ціль функціонування якого - гарантування фінансового відшкодування постраждалим учасникам ДТП.

Даний вид страхування займає один з ключових сегментів страхового ринку у всіх розвинених країнах світу. Корисним є досвід європейських країн, в яких вказаний вид страхування існує з тридцятих - сороко- 